\section{Recognizing good teaching}

SIR-In the 17 March 1988 issue, Nature reviewed the achievements of secondary school students in biology, chemistry and physics in 17 countries', based on a US National Science Foundation (NSF) survey'. The ranking is startling, and you quote appropriately that "for a technologically advanced country [USA], it would appear that a reexamination of how science is presented and studied is required"1. Improving education is an important and complex task.

A recent issue of the Chronicle of Higher Education ${ }^{3}$ gives a 30-point guideline for the measurement of excellence in a teacher. Only the eighteenth rank is assigned to the criterion "are knowledgeable about their work". I believe mastery of the subject is the most important requisite. The article quotes a professor as saying that teacher evaluation "emphasizes the superficial". Among the 30 points, nothing is said about course content relative to students' preparation and need. The guidelines do not expect an excellent teacher to teach principles rather than data. The good teacher does not teach by rote but must show the ways hypotheses are conceived, tested and applied. In the NSF report, it is not considered a very important feature of a good teacher that he or she weighs the subject, integrates the facts into theory and is upto-date and relevant. Is it not an absolute necessity to use plain and expressive language, rather than to "give corrective feedback promptly to students"? It is less important that the teacher should "provide clear and substantial evidence that the students have learned" than that the students feel they have gained by the instruction. The measure of the effectiveness of teaching is not the enthusiasm of the instructor but how much interest and enthusiasm he can generate. The good teacher inspires the students, is patient with the learner, shows interest in individuals and cares for them.

Teacher evaluation is important and cannot be dealt with in the way suggested by the guidelines. The Chronicle aptly quotes someone who says that one such evaluation "generated mostly paperwork". It is bad enough that at many institutions research is judged by number of publications rather than by their quality and/or impact. Some administrators advocate evaluation based on "market value", thereby admitting their inability to make a sound judgement, and confusing commodities such as eggs with eggheads. There is one solid criterion of an excellent teacher: her/his students know more than those of an average good instructor and have learned by less painful ways. They understand the subject better and can apply the principles more effectively and ethically. This gain by the students can be objectively assessed, and the best teachers can thereby be recognized.

University of Missouri,

Columbia, Missouri 65211, USA

1. Ezzell. C. Nature 332. 195 (1988)

2. Science and Achievement in Seventeen Countries. (US National Science Foundation, Office of Studies and Program Assessment. Washington, DC 1988.)

The Chronicle of Higher Education 34, A13, A15 (1988).

\section{Opportunities in India}

SIR-K. S. Jayaraman's article (Nature 333, 201; 1988) about an apparent halt of the brain drain from India distorts the facts. It is time that these ambiguities were clarified to avoid any further wishful thinking on the part of the scientific community in general and the Indian Department of Science and Technology in particular. The fact is that the apparent halt in the brain drain is a consequence of changes in Western immigration policies. In the mid-1970s, immigration laws in the United States and United Kingdom were lenient, allowing graduates to move to these countries. Immigration laws are now much more stringent; only 2 per cent of Indian graduates are taken by these countries. It is therefore wrong to assume that the decrease in the brain drain is due to an increase in opportunities in India.

Perhaps some young scientists of Indian origin who have made names for themselves would like to return to help bring science in their home country to the forefront and some of them even leave wellpaid jobs to do so, but unfortunately this is at present only a one-sided effort. The Department of Science and Technology is keeping a register of graduates who wish to return to India, but the real issue is whether anything is being done to give them incentives.

Foreign graduates face two major problems. First, their way of tackling scientific research is different from that of graduates trained by the bureaucratic older generation of Indian scientists, who feel threatened by the foreign-trained invaders. Second, they have to face the ingrained bureaucratic attitudes of the older generation. These problems will not be solved unless the foreign-trained and capable young scientists have senior positions. There is a formidable number of new institutes being built by Indian science and technology, and financial support from WHO, UNO and the United States is going into the system. Real scientific research will happen only when the science in these buildings is carried out with purposeful objectives.

12901 Cottage Mill Place,

Balbir S. BhOGal

Midlothian, Virginia 23113, USA

\section{Pain and the fetus}

\section{SIR-The debate generated by David} Alton's attempt to amend the 1967 Abortion Act ranged widely. But one question that it failed to address, which to me, as a neuroscientist, is perhaps the most compelling, is the possibility that severe pain is experienced by the fetus undergoing late termination. I have heard no informed argument on this matter and, as a result, remain worried by the possibility that as a society we are sanctioning an inhuman practice.

There is detailed legislation relating to pain and laboratory animals, and I wonder whether there is some inconsistency between that regulation and what appears to be a lack of information and controls over dealings with human fetuses.

D.E. Marple-Horvat

Department of Physiology,

University of Bristol Medical School, University Walk, Bristol BS8 1TD, UK

\section{Waiting refusniks}

SiR-Your leading article (Nature 333, $483 ; 1988)$ asserts that those who champion the cause of Soviet refusniks may be flogging last decade's horse.

I agree; but it is not the fault of those who try to help refusniks that the Soviet Union has failed to drag this particular horse into the $1980 \mathrm{~s}$. We welcome many of the changes now taking place in the Soviet Union. But we would welcome them still more if they led to the release of refusniks such as Oskar Mendeleev or Vladimir Raiz, who have been waiting for exit visas since the early 1970 s So long as the Soviet Union tries to have us believe that a protein crystallographer who left his work in 1973 still retains secret information of importance to the security of the state, there will be many in the West who remain sceptical of its intentions about more fundamental matters.

$$
\text { M. D. YUDKIN }
$$

Scientists for the Release

of Soviet Refusniks,

$4 A$ New College Parade,

London NW3 $5 E P, U K$

\section{No energy}

SIR-In "Explosive fragments by numbers" (Nature 332, 775; 1988), John Maddox fails to include the translational kinetic energy of the shell. This means that, in the limiting case of one fragment (no explosion), the available destructive energy is zero. The implication would be that we have nothing to fear from a rifle bullet. Kinetic energy SDI systems would also be contraindicated.

Physics Department,

EdWARd DERringh

Wentworth Institute of Technology,

Boston, Massachusetts 02115, USA 